\title{
Titania Particle Size Effect on the Overall Performance of Dye-Sensitized Solar Cells
}

\author{
Tammy P. Chou, ${ }^{\dagger}$ Qifeng Zhang, ${ }^{\dagger}$ Bryan Russo, ${ }^{\dagger}$ Glen E. Fryxell, ${ }^{\ddagger}$ and Guozhong Cao $*, \dagger$ \\ Materials Science \& Engineering, University of Washington, 302 Roberts Hall, Box 352120, Seattle, \\ Washington 98195, and Institute for Interfacial Catalysis (IIC), Pacific Northwest National Laboratory (PNNL), \\ 902 Battelle Boulevard, Box 999, Richland, Washington 99352
}

Received: December 26, 2006; In Final Form: February 27, 2007

\begin{abstract}
In this paper, we report the solar cell performance of titania $\left(\mathrm{TiO}_{2}\right)$ film electrodes with various particle sizes. It was found that the $\mathrm{TiO}_{2}$ nanoparticle film with smaller particles $\sim 10 \mathrm{~nm}$ in diameter resulted in a lower overall light conversion efficiency of $\sim 1.4 \%$ with an open-circuit voltage of $\sim 730 \mathrm{mV}$, a short-circuit current density of $\sim 3.6 \mathrm{~mA} / \mathrm{cm}^{2}$, and a fill factor of $\sim 54 \%$. Larger particles $\sim 23 \mathrm{~nm}$ in diameter resulted in a higher efficiency $\sim 5.2 \%$ with an open-circuit voltage of $\sim 730 \mathrm{mV}$, a short-circuit current density of $\sim 12.2 \mathrm{~mA} /$ $\mathrm{cm}^{2}$, and a fill factor of $\sim 58 \%$. Although it was anticipated that particles with smaller diameters would adsorb more dye because of their larger surface area, it was found that particles with larger diameters had better dye adsorption for increased electron-hole generation, resulting in higher short-circuit current density and overall light conversion efficiency. Larger particles were shown to have better dye adsorption, indicating that films consisting of larger particles had greater effective surface area for greater photon absorption and electron-hole generation.
\end{abstract}

\section{Introduction}

With the emergence of nanotechnology and the fabrication of various oxide materials in the nanoscale, opportunities for developing new-age solar cells have surfaced. ${ }^{1,2}$ The exploration of light absorption and photocurrent generation in the conversion of solar energy to electrical energy is in the nanoscale. ${ }^{3}$ Thus, it is reasonable that the exploration in the development and control of semiconductor materials at the nanometer scale for use in solar cells has emerged. ${ }^{4-6}$

To this point, the most efficient electrodes in dye-sensitized solar cells have been $10 \mu \mathrm{m}$ thick mesoporous $\mathrm{TiO}_{2}$ film consisting of an interconnected network of nanometer-sized crystals $\sim 20 \mathrm{~nm}$ in size. ${ }^{7,8}$ It has been shown that this type of structure $^{9-11}$ imparts a large enough surface area for suitable dye adsorption, efficient light absorption, and charge formation. In 1993, it was found that dye-sensitized solar cells were able to attain efficiencies close to $\sim 10 \% .^{12}$ Two decades later, efficiencies have only gone up to $\sim 11 \%,{ }^{13,14}$ which is so far the highest efficiency obtained.

One area that has not been systematically explored is the particle size of the $\mathrm{TiO}_{2}$ film electrode. By utilizing electrodes consisting of smaller or larger $\mathrm{TiO}_{2}$ particles, an understanding of the effects of particle size on the overall solar cell performance of dye-sensitized solar cells can be obtained.

There are a few advantages associated with using smaller or larger particles, which can influence the solar cell performance. Films with larger particles have larger contact points between sintered colloidal particles or at the interface between the particles and the underlying substrate, allowing for easier dye access and better dye assembly. Films with smaller particles have a larger surface area and have a greater number of contact

* To whom correspondence should be addressed. E-mail: gzcao@ u.washington.edu.

$\dagger$ University of Washington.

$\doteqdot$ Pacific Northwest National Laboratory. points between sintered colloidal particles or at the interface between the particles and the underlying substrate, allowing for greater dye adsorption.

However, utilizing larger or smaller particles has disadvantages as well. Films consisting of larger particles have a smaller surface area, where less surface is available for dye adsorption, possibly reducing the amount of light absorbed and the number of electrons and holes generated. Films consisting of smaller particles exhibit a larger number of grain boundaries where electrons need to pass through, which results in a higher probability of electron trapping. ${ }^{15-18}$

In this report, solar cell electrodes consisting of $\mathrm{TiO}_{2}$ nanoparticle film with varying particle sizes were studied and compared to determine whether the electron-transport properties and the overall light conversion efficiency are influenced by the differences in particle size. The particle size of $\mathrm{TiO}_{2}$ was varied from $\sim 9 \mathrm{~nm}$ to $\sim 23 \mathrm{~nm}$ in diameter by way of hydrothermal crystallization ${ }^{19,20}$ at varying temperatures for 60 min. Films were fabricated from all hydrothermally treated $\mathrm{TiO}_{2}$ nanoparticle powders and were tested under illumination, and the $\mathrm{I}-\mathrm{V}$ behavior of all $\mathrm{TiO}_{2}$ nanoparticle films from solar cell analysis was compared.

\section{Experimental Procedures}

(1) Fabrication of $\mathrm{TiO}_{2}$ Nanoparticles. Titania $\left(\mathrm{TiO}_{2}\right) \mathrm{sol}^{21}$ was prepared from precursor materials by way of sol-gel processing. The chemicals used in making $\mathrm{TiO}_{2}$ sol were titanium(IV) isopropoxide (97\%, Alfa Aesar, Ward Hill, MA), glacial acetic acid (Fisher Scientific, Fair Lawn, NJ), and deionized water. All the $\mathrm{TiO}_{2}$ nanoparticle films were prepared on transparent, conductive fluorine-tin-oxide (FTO)-coated glass substrates (TCO10-10, $R_{\mathrm{S}} \sim 10 \mathrm{ohm} / \mathrm{sq}$, Solaronix SA, Switzerland) for film characterization and solar cell analysis.

The sol was prepared by dissolving titanium(IV) isopropoxide [ $\left.\mathrm{Ti}\left(\mathrm{OCH}\left(\mathrm{CH}_{3}\right)_{2}\right)_{4}\right]$ in glacial acetic acid $\left[\mathrm{CH}_{3} \mathrm{CO}_{2} \mathrm{H}\right]$ and by adding deionized water $\left(\mathrm{DI}-\mathrm{H}_{2} \mathrm{O}\right)$ to give a nominal molar ratio 
of 1.02:10.5:16.6 for $\mathrm{Ti}\left[\mathrm{OCH}\left(\mathrm{CH}_{3}\right)_{2}\right]_{4}: \mathrm{CH}_{3} \mathrm{CO}_{2} \mathrm{H}: \mathrm{DI}-\mathrm{H}_{2} \mathrm{O}$, respectively. The solution was stirred for approximately $30 \mathrm{~min}$ at room temperature after the instantaneous formation of a white precipitate disappeared and the solution became clear. The resultant sol had a $\mathrm{pH}$ value of $\sim 2$, resulting in positively charged $\mathrm{TiO}_{2}$ sol particles since the $\mathrm{pH}$ is lower than its isoelectric point (IEP 6.2). The sol was clear and stable at room temperature for up to 7 days but was stored at $-20{ }^{\circ} \mathrm{C}$ when not in use to minimize reactions. Sonication for $10 \mathrm{~min}$ was done to bring the sol back to room temperature and to disperse the sol particles before use.

The $\mathrm{TiO}_{2}$ nanoparticle powders were obtained by hydrothermally treating $\mathrm{TiO}_{2}$ sol using a small autoclave. Using this type of sealed reaction chamber allowed for low-temperature heating and relied on a higher pressure in an aqueous environment for crystallization of $\mathrm{TiO}_{2}$. For each hydrothermal treatment, approximately $10 \mathrm{~mL}$ of $\mathrm{TiO}_{2}$ sol was placed in a polytetrafluoroethylene cup (PTFE, Parr Instrument Co, Moline, Il) and was sealed in an acid digestion bomb (Parr Instrument Co, Moline, Il). The entire chamber was then heated to as high as $300{ }^{\circ} \mathrm{C}$ (the maximum temperature allowable for this type of chamber) for $60 \mathrm{~min}$ and as low as $100{ }^{\circ} \mathrm{C}$ for $60 \mathrm{~min}$. Hydrothermal treatment was performed for $60 \mathrm{~min}$ at 100, 150, 200, 250, or $300{ }^{\circ} \mathrm{C}$ to study the variation in particle size by varying the hydrothermal treatment temperature. After heating to a specific temperature and time, the sol became a pastelike substance in all cases. This was then allowed to dry at $100{ }^{\circ} \mathrm{C}$ for $24 \mathrm{~h}$ and the resultant crystals were ground into a powder using a mortar and pestle.

(2) Fabrication of $\mathrm{TiO}_{2}$ Nanoparticle Films. For solar cell testing, $\mathrm{TiO}_{2}$ nanoparticle films with $\sim 10 \mu \mathrm{m}$ thickness were prepared from the various hydrothermally treated $\mathrm{TiO}_{2}$ nanoparticle powders. Samples of $10 \mu \mathrm{m}$ thick $\mathrm{TiO}_{2}$ nanoparticle film were directly deposited onto conductive fluorine-tin-oxide (FTO) glass substrates by doctor-blading a dispersion of 20$30 \mathrm{wt} \%$ powder in ethanol solution. Before preparing the film, the surfaces of the FTO substrates were hydrolyzed by heating to $90-100{ }^{\circ} \mathrm{C}$ in $\mathrm{DI}-\mathrm{H}_{2} \mathrm{O}$ for $30-60 \mathrm{~min}$.

After the substrates were air-dried, two parallel edges of each substrate were covered with $\sim 10 \mu \mathrm{m}$ thick scotch tape to control the thickness of the film. To form the film, five drops of the powder dispersion were placed at the center of each substrate and the edge of a glass microscope slide was used to spread the solution to form an even $10 \mu \mathrm{m}$ layer after sliding over the tape-covered edges. The film was then dried in air at $100{ }^{\circ} \mathrm{C}$ for $1 \mathrm{~h}$ and was sintered at $500{ }^{\circ} \mathrm{C}$ for $1 \mathrm{~h}$ at a heating rate of $2{ }^{\circ} \mathrm{C} / \mathrm{min}$.

Before solar cell testing, the $\mathrm{TiO}_{2}$ films were heated to 70 ${ }^{\circ} \mathrm{C}$ and subsequently were immersed in standard rutheniumbased red dye (N3), cis-bis(isothiocyanato)bis(2,2'-bipyridyl4,4'-dicarboxylato)ruthenium(II) (Solterra Fotovoltaico SA, Switzerland), with a concentration close to $5 \times 10^{-4} \mathrm{M}$ in ethanol for $\sim 12 \mathrm{~h}$. The samples were then rinsed with ethanol to remove excess dye on the surface and were air-dried at room temperature.

(3) Solar Cell Assembly. Colloidal liquid silver (Ted Pella Inc., Redding, CA) was placed at the electrical contacts to improve the contact points and was allowed to cure for $30 \mathrm{~min}$ at room temperature. Sheets of weigh paper $\sim 30-40 \mu \mathrm{m}$ thick were cut into small pieces $\sim 1 \mathrm{~mm} \times 4 \mathrm{~mm}$ in dimension and were used as spacers. A spacer was placed at each edge of the $\mathrm{TiO}_{2}$ working electrode and the counter electrode consisting of a Pt-coated silicon ( $\mathrm{Si}$ ) substrate with a Pt layer thickness of $\sim 180 \mathrm{~nm}$ was placed on top, with the Pt-coated side of each $\mathrm{Si}$ substrate facing the $\mathrm{TiO}_{2}$ working electrode. Each solar cell was held in place with two heavy duty clips on opposite ends.

An iodide-based solution was used as the liquid electrolyte, consisting of $0.6 \mathrm{M}$ tetra-butylammonium iodide (SigmaAldrich, St. Louis, MO), 0.1 M lithium iodide (LiI, SigmaAldrich, St. Louis, MO), $0.1 \mathrm{M}$ iodine $\left(\mathrm{I}_{2}\right.$, Sigma-Aldrich, St. Louis, MO), and 0.5 M 4-tert-butyl pyridine (Sigma-Aldrich, St. Louis, MO) in acetonitrile (Mallinckrodt Baker, Phillipsburg, $\mathrm{NJ})$. Right before analysis, drops of the liquid electrolyte were introduced to one edge of the sandwich, where capillary force was used to spread the liquid electrolyte in between the two electrodes. The light source was placed next to each solar cell device, allowing light to penetrate through the FTO back contact to the dye adsorbed onto the $\mathrm{TiO}_{2}$ nanoparticle film electrode.

(4) Amount of Dye Adsorption. The amount of dye adsorbed was determined for all the $\mathrm{TiO}_{2}$ nanoparticle powders and films with various particle sizes using the method of dye elution, which has been commonly used in controlled drug release studies. ${ }^{22}$ Approximately $0.02 \mathrm{~g}$ of each $\mathrm{TiO}_{2}$ powder was immersed in $5 \mathrm{~mL}$ of $\mathrm{N} 3$ dye for $\sim 24 \mathrm{~h}$. Each $\mathrm{TiO}_{2}$ film on FTO was immersed in $5 \mathrm{~mL}$ of $\mathrm{N} 3$ dye for $\sim 24 \mathrm{~h}$. The immersed powders were separated from the dye solution by centrifugation for $\sim 2 \mathrm{~min}$, and the immersed films were directly removed to analyze the resultant dye solution after dye adsorption. The intensity of the absorption peak of the resultant dye solution after dye adsorption was compared to the absorption peak of the initial N3 dye solution with a concentration of $\sim 5 \times 10^{-4}$ $\mathrm{M}$ in ethanol to determine the number of moles adsorbed.

(5) Analysis Techniques. X-ray Diffraction (Philips PW1830 Diffractometer) was used to verify the phase, crystal structure, and particle size of the $\mathrm{TiO}_{2}$ nanoparticle powders and films. The diffractometer was set at $40 \mathrm{kV}$ working voltage and 20 $\mathrm{mA}$ working ampere. Powder samples were placed in a polymer holder and were placed into the diffractometer for analysis, and film samples were attached to a glass slide and were inserted into the diffractometer for analysis. All samples were scanned from $20^{\circ}$ to $80^{\circ} 2 \theta$ at a rate of 0.02 scans/second using X'Pert Industry Philips XRD software. The particle sizes of the various prepared powders and films were also analyzed using JADE software (MDI JADE 7 Materials Data XRD Pattern Processing, Identification, and Quantification).

Scanning electron microscopy (SEM) (JEOL JSM-5200, JEOL 840A, JSM-7000) was used to study the morphology of the $\mathrm{TiO}_{2}$ nanoparticles and films. The powders and films were placed on an aluminum SEM stub, using either conductive carbon tape or a layer of silver paste for attachment. All samples were sputter-coated with a thin layer of $\mathrm{Au} / \mathrm{Pd}$ or Pt prior to SEM observation for better imaging. The images were obtained at $15 \mathrm{kV}$ from $5000 \times$ up to $80000 \times$ magnification, depending on the sample.

Electrical characteristics and photovoltaic properties of each solar cell were measured using simulated AM1.5 sunlight illumination with $100 \mathrm{~mW} / \mathrm{cm}^{2}$ light output. An ultraviolet solar simulator (Model 16S, Solar Light Co., Philadelphia, PA) with a $200 \mathrm{~W}$ xenon lamp power supply (Model XPS 200, Solar Light Co., Philadelphia, PA) was used as the light source, and a semiconductor parameter analyzer (4155A, Hewlett-Packard, Japan) was used to measure the current and voltage. The intensity of the light source provided by the xenon lamp was measured with a photometer/radiometer (PMA2200, Solar Light Co., Philadelphia, PA) connected with a full spectrum pyranometer (PMA2141, Solar Light Co., Philadelphia, PA). All the $\mathrm{I}-\mathrm{V}$ curves of the solar cells were obtained in the dark and under illumination, where a voltage range from -0.3 to $2 \mathrm{~V}$ 
was used during each measurement. The $\mathrm{I}-\mathrm{V}$ characteristics as a function of incident light intensity were used to obtain the open-circuit voltage $\left(V_{\mathrm{oc}}\right)$, short-circuit current density $\left(J_{\mathrm{sc}}\right)$, the maximum voltage point $\left(V_{\max }\right)$, and the maximum current density point $\left(J_{\max }\right)$. Multiple samples were tested for each $\mathrm{TiO}_{2}$ film with specific particle size, resulting in reproducible results with slight deviations in the short-circuit current $(\sim \pm 0.05 \mathrm{~mA})$, open-circuit voltage $(\sim \pm 10 \mathrm{mV})$, and the light conversion efficiency $(\sim \pm 0.02 \%)$.

Optical absorption (Ocean Optics Inc, Dunedin, FL) was used to analyze the absorption peak of the resultant dye solutions after dye adsorption on the $\mathrm{TiO}_{2}$ nanoparticle powders and films to determine the amount of dye adsorbed on the surface. The solutions were placed in cuvettes and were scanned in the analysis chamber from 900 to $400 \mathrm{~nm}$ wavelengths using Ocean Optics software. The solution used as the background sample was ethanol. The intensity of the absorption peak of the resultant dye solution was compared to the intensity of the absorption peak of the initial dye solution.

The surface area was based on theoretical values using the crystal size results from X-ray diffraction (XRD) analysis. Initial BET (Brunaeur-Emmett-Teller) analysis was performed on one $\mathrm{TiO}_{2}$ powder sample (hydrothermal treatment at $250{ }^{\circ} \mathrm{C}$ for $60 \mathrm{~min}$ ) and was compared to the theoretical value through calculations using the following equations:

$$
\begin{gathered}
\mathrm{SA}=\left(\#_{\text {particles }} \times A_{\text {particle }}\right) \div W_{\text {sample }} \\
\#_{\text {particles }}=V_{\text {sample }} \div V_{\text {particle }}=\pi R^{2} h \div\left(\frac{4}{3}\right) \pi r^{2} \\
A_{\text {particle }}=4 \pi r^{2} \times 10^{-4}
\end{gathered}
$$

where $\mathrm{SA}=$ surface area in $\mathrm{m}^{2} / \mathrm{g}, \#_{\text {particles }}=$ number of particles, $A_{\text {particle }}=$ area of each particle in $\mathrm{m}^{2}, W_{\text {sample }}=$ total sample weight in $\mathrm{g}, V_{\text {sample }}=$ volume of sample area in $\mathrm{cm}^{3}, V_{\text {particle }}=$ volume of each spherical particle in $\mathrm{cm}^{3}, R=$ radius of sample area in $\mathrm{cm} \sim 0.4, h=$ thickness of film sample in $\mathrm{cm} \sim 0.001$, $r=$ radius of each particle in $\mathrm{cm}$.

The surface area values found from BET were very similar to that found from theoretical calculation with a difference of $\sim 0.2 \mathrm{~m}^{2} / \mathrm{g}$. Therefore, the same calculations were done for all the $\mathrm{TiO}_{2}$ powder samples on the basis of the particle size and those values were used as the estimated surface areas.

\section{Results and Discussion}

XRD analysis was done on $\mathrm{TiO}_{2}$ nanoparticle powders obtained by hydrothermal treatment for $60 \mathrm{~min}$ at temperatures of $100,150,200,250$, and $300{ }^{\circ} \mathrm{C}$ and on $\mathrm{TiO}_{2}$ films prepared from the hydrothermally treated $\mathrm{TiO}_{2}$ powders. Additional SEM analysis was also used to examine the film morphology; however, it was difficult to see any distinction between the various films, as the variation in particle size among the films was in the nanometer range $(<12 \mathrm{~nm})$, as found from XRD analysis. In addition, the resolution of the SEM was not sufficient enough to distinguish any differences between the nanometer-sized particles and to determine the pore structure. Therefore, the results from XRD analysis were sufficient enough to compare the particle sizes of the various films, and the resultant particle sizes were used to estimate the surface area.

Figure 1 shows the XRD patterns of the $\mathrm{TiO}_{2}$ powders obtained by hydrothermal treatment at various temperatures. It can be seen that the crystallinity improves as the hydrothermal treatment temperature increases, all showing the anatase phase

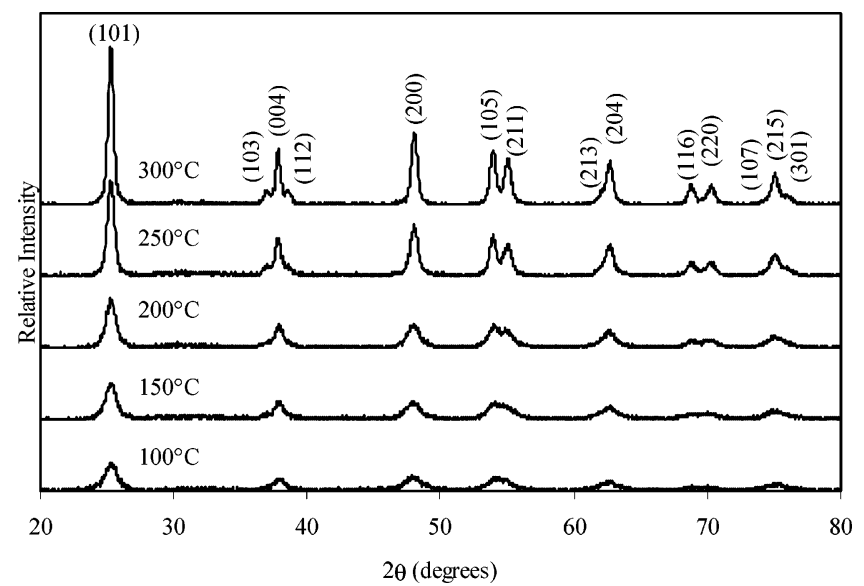

Figure 1. XRD peaks of $\mathrm{TiO}_{2}$ nanoparticle powders obtained by hydrothermal treatment for $60 \mathrm{~min}$ at $100,150,200,250$, and $300{ }^{\circ} \mathrm{C}$ temperatures. The peaks represent the anatase phase of $\mathrm{TiO}_{2}$.

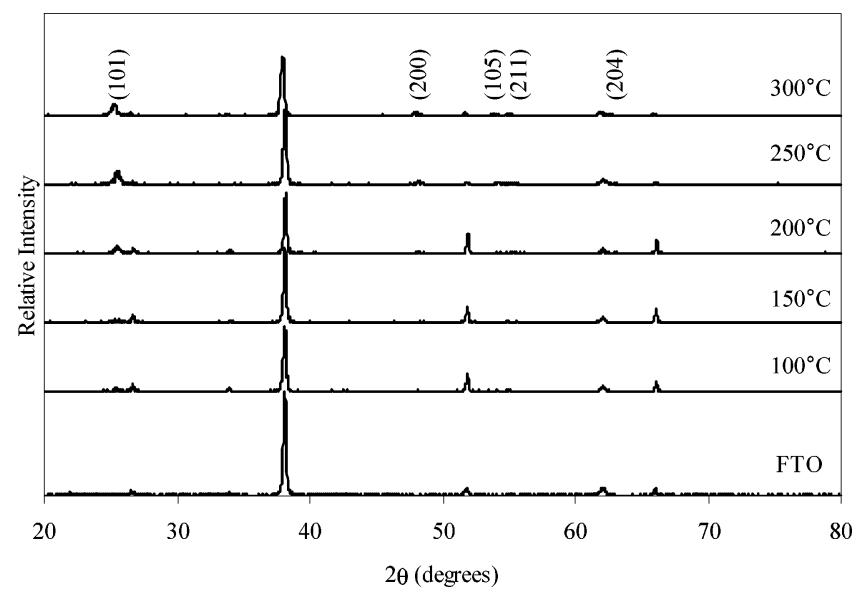

Figure 2. XRD peaks of $\mathrm{TiO}_{2}$ nanoparticle films obtained from hydrothermally treated $\mathrm{TiO}_{2}$ nanoparticle powders, showing that the anatase phase is present. Extra peaks are from the underlying FTO substrate.

of $\mathrm{TiO}_{2}$. Figure 2 shows the XRD patterns of the $\mathrm{TiO}_{2}$ films made from the same $\mathrm{TiO}_{2}$ powders on FTO substrates and sintered at $500{ }^{\circ} \mathrm{C}$ for $1 \mathrm{~h}$. The XRD pattern of FTO is also shown for comparison. Although the intensity of the peaks is too small, it was found that the (101), (200), (105), (211), and (204) peaks are present for all the films, representing the anatase phase of $\mathrm{TiO}_{2}$. Additional peaks in the XRD figure represent the FTO substrate.

By analyzing the XRD peaks, the particle sizes of each $\mathrm{TiO}_{2}$ powder and film sample were calculated. The (101), (200), and (211) peaks were used to estimate the particle size of each $\mathrm{TiO}_{2}$ powder and film sample by averaging the particle sizes at each peak for each $\mathrm{TiO}_{2}$ sample. These three peaks were present for both powder and film form; therefore, these peaks were used to estimate the particle size. The particle sizes were estimated at each peak using the Scherer equation: ${ }^{23}$

$$
t=(0.9 \lambda) \div\left(B \cos \theta_{\mathrm{B}}\right)
$$

where $t$ is the particle size in angstroms, $\lambda$ is equal to 1.54056 $\AA$, the wavelength for $\mathrm{Cu} \mathrm{K \alpha _{1 }}$ radiation, $B$ is the width of the peak at an intensity equal to half the maximum intensity in radians, and $\theta_{\mathrm{B}}$ is the diffracted angle at maximum intensity. Table 1 summarizes the actual particle sizes of (1) $\mathrm{TiO}_{2}$ powders obtained at various hydrothermal treatment temperatures for 60 min and (2) $\mathrm{TiO}_{2}$ films prepared from the various $\mathrm{TiO}_{2}$ powders 
TABLE 1: Comparison of the Average Particle Size of $\mathrm{TiO}_{2}$ Nanoparticle Powders and Films Obtained from Hydrothermal Crystallization at Various Temperatures for $60 \min ^{a}$

\begin{tabular}{cccc}
\hline & & \multicolumn{2}{c}{ average particle size $(\mathrm{nm})$} \\
\cline { 3 - 4 } temperature $\left({ }^{\circ} \mathrm{C}\right)$ & time (minutes) & powder & film \\
\hline 100 & 60 & 6.72 & 9.80 \\
150 & 60 & 7.06 & 10.7 \\
200 & 60 & 9.66 & 15.3 \\
250 & 60 & 13.6 & 18.9 \\
300 & 60 & 17.7 & 22.5
\end{tabular}

${ }^{a}$ The $\mathrm{TiO}_{2}$ films had additional sintering treatment at $500{ }^{\circ} \mathrm{C}$ for 60 min after deposition on FTO substrates.

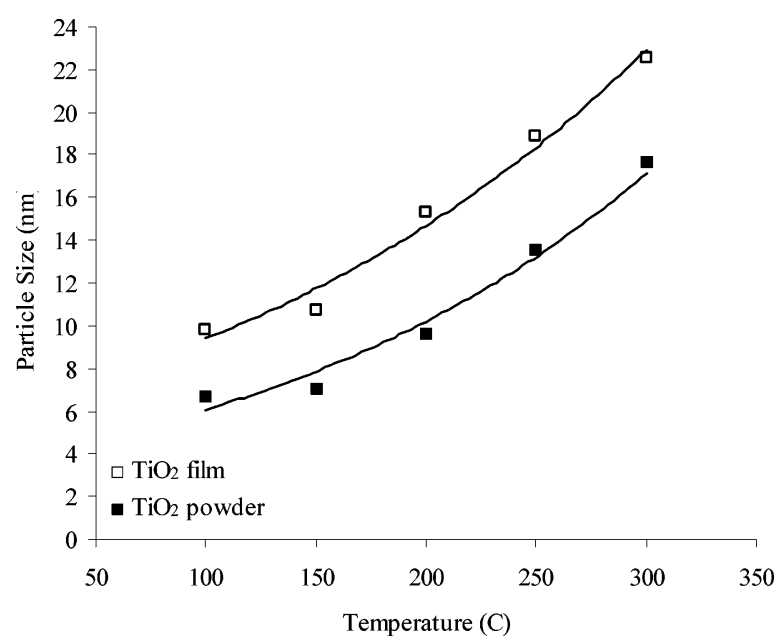

Figure 3. Comparison of the particle size as a function of the hydrothermal treatment temperature. All samples were treated for 60 $\mathrm{min}$ at various temperatures, as indicated. Additional sintering at 500 ${ }^{\circ} \mathrm{C}$ for 60 min was performed for all the film samples.

and sintered at $500{ }^{\circ} \mathrm{C}$ for $1 \mathrm{~h}$. Figure 3 is a comparison of the particle size for $\mathrm{TiO}_{2}$ nanoparticle powders and films, relative to the temperature used to hydrothermally treat $\mathrm{TiO}_{2}$ for $60 \mathrm{~min}$.

The particle size correlates with the temperature used, where the size increases with increasing temperature. It has been estimated that sol particles prepared through sol-gel processing are $\sim 4 \mathrm{~nm}$ in size. With additional hydrothermal treatment, the particle size increased to $\sim 6.7 \mathrm{~nm}$ at $100{ }^{\circ} \mathrm{C}, \sim 7.1 \mathrm{~nm}$ at 150 ${ }^{\circ} \mathrm{C}, \sim 9.7 \mathrm{~nm}$ at $200{ }^{\circ} \mathrm{C}, \sim 13.6 \mathrm{~nm}$ at $250{ }^{\circ} \mathrm{C}$, and $\sim 17.7 \mathrm{~nm}$ at $300{ }^{\circ} \mathrm{C}$. With further $500{ }^{\circ} \mathrm{C}$ sintering for $1 \mathrm{~h}$ after film formation, the particle size increased further to $\sim 9.8 \mathrm{~nm}$ at 100 ${ }^{\circ} \mathrm{C}, \sim 0.7 \mathrm{~nm}$ at $150{ }^{\circ} \mathrm{C}, \sim 5.3 \mathrm{~nm}$ at $200{ }^{\circ} \mathrm{C}, \sim 18.9 \mathrm{~nm}$ at 250 ${ }^{\circ} \mathrm{C}$, and $\sim 22.5 \mathrm{~nm}$ at $300{ }^{\circ} \mathrm{C}$. Additional sintering of the films at $500{ }^{\circ} \mathrm{C}$ for $60 \mathrm{~min}$ was necessary to initiate sintering of contact points between particles and between particles and the underlying substrate to have sufficient electrical contact for the purpose of solar cell testing. In addition, since the hydrothermal chamber was limited to a temperature of $300{ }^{\circ} \mathrm{C}$ without rupture, higher temperatures were not used to possibly increase the particle size even further.

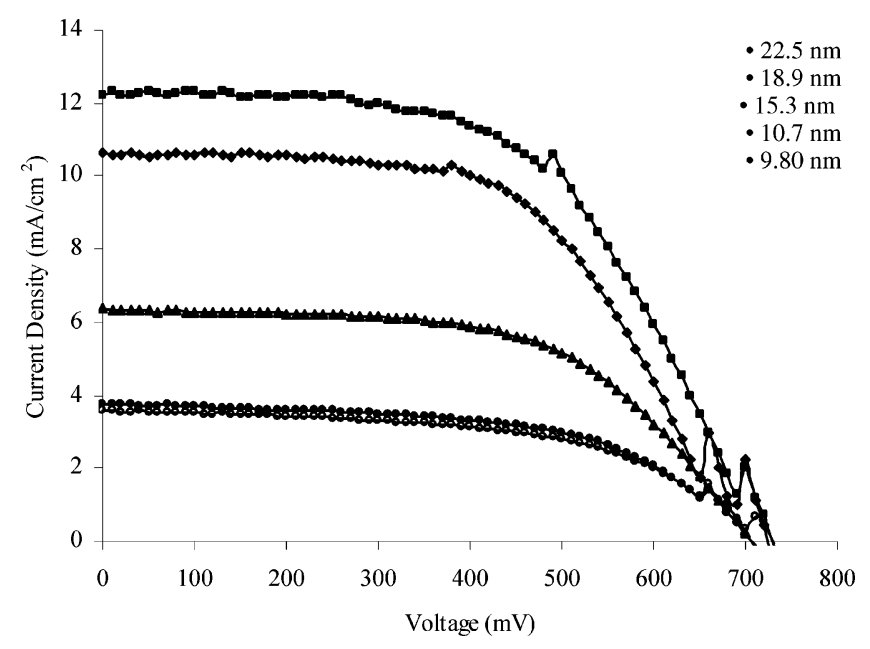

Figure 4. Plot of the $\mathrm{I}-\mathrm{V}$ behavior of solar cells consisting of $\mathrm{TiO}_{2}$ nanoparticle films with various particle sizes. The overall light conversion efficiency was calculated from the short-circuit current density, open-circuit voltage, and the maximum output values.

To compare the particle size effect on the overall performance of $\mathrm{TiO}_{2}$ film electrodes, solar cell analysis was performed on $\mathrm{TiO}_{2}$ films with various particle sizes. Solar cells consisting of $\mathrm{TiO}_{2}$ film electrodes with $\mathrm{TiO}_{2}$ particles with $\sim 9.8, \sim 10.7$, $\sim 15.3, \sim 18.9$, and $\sim 22.5 \mathrm{~nm}$ diameters were assembled and tested under illumination with $100 \mathrm{~mW} / \mathrm{cm}^{2}$ intensity. Figure 4 compares the $\mathrm{I}-\mathrm{V}$ characteristics of each solar cell consisting of $\mathrm{TiO}_{2}$ film with varying particle size as indicated. Table 2 summarizes the measured and calculated values obtained from the I-V curves of each solar cell. It can be seen that the opencircuit voltage and the fill factor remained fairly constant in the range of $\sim 720 \mathrm{mV}$ and $\sim 56 \%$, respectively. This trend is expected since the $\mathrm{TiO}_{2}$ nanoparticle powders and films were all prepared from the same $\mathrm{TiO}_{2}$ sol and were prepared in the same manner therefore resulting in the same surface chemistry and particle packing. The most notable trend is the change in short-circuit current density and overall light conversion efficiency, which correlates with the particle size.

The slight change in particle size from $\sim 9.8 \mathrm{~nm}$ to $\sim 10.7$ $\mathrm{nm}$ resulted in a small increase in short-circuit current density from $\sim 3.6 \mathrm{~mA} / \mathrm{cm}^{2}$ to $\sim 3.8 \mathrm{~mA} / \mathrm{cm}^{2}$ and a slight increase in overall light conversion efficiency from $\sim 1.4 \%$ to $\sim 1.5 \%$, respectively. A larger increase in particle size resulted in a larger increase in short-circuit current density and overall light conversion efficiency. The short-circuit current density increased further to $\sim 6.4, \sim 10.6$, and $\sim 12.2 \mathrm{~mA} / \mathrm{cm}^{2}$ with a further increase in particle size to $\sim 15.3, \sim 18.9$, and $\sim 22.5 \mathrm{~nm}$, respectively. In addition, the overall light conversion efficiency increased to $\sim 2.6, \sim 4.3$, and $\sim 5.2 \%$ with the increase in particle size to $\sim 15.3, \sim 18.9$, and $\sim 22.5 \mathrm{~nm}$, respectively. Figure 5 is a plot of short-circuit current density $\left(J_{\mathrm{sc}}\right)$ and overall light conversion efficiency $(\eta)$ as a function of $\mathrm{TiO}_{2}$ particle size.

It is thought that the increasing trend in short-circuit current density and overall light conversion efficiency relative to the

TABLE 2: Summary of the Open-Circuit Voltage, Short-Circuit Current Density, Maximum Voltage and Current Output, Fill Factor, Power Output, and Overall Light Conversion Efficiency Relative to the $\mathrm{TiO}_{2}$ Particle Size

\begin{tabular}{ccccccccc}
\hline $\begin{array}{c}\text { particle size } \\
(\mathrm{nm})\end{array}$ & $\begin{array}{c}V_{\mathrm{oc}} \\
(\mathrm{mV})\end{array}$ & $\begin{array}{c}J_{\mathrm{sc}} \\
\left(\mathrm{mA} / \mathrm{cm}^{2}\right)\end{array}$ & $\begin{array}{c}V_{\max } \\
(\mathrm{mV})\end{array}$ & $\begin{array}{c}J_{\max } \\
\left(\mathrm{mA} / \mathrm{cm}^{2}\right)\end{array}$ & $\begin{array}{c}\mathrm{FF} \\
(\%)\end{array}$ & $\begin{array}{c}P_{\max } \\
\left(\mathrm{mW} / \mathrm{cm}^{2}\right)\end{array}$ & $\begin{array}{c}P_{\text {in }} \\
\left(\mathrm{mW} / \mathrm{cm}^{2}\right)\end{array}$ & $\begin{array}{c}\eta \\
(\%)\end{array}$ \\
\hline 9.80 & 730 & 3.59 & 510 & 2.75 & 53.5 & 1.40 & 1.700 & 1.40 \\
10.7 & 710 & 3.75 & 500 & 2.98 & 56.0 & 1.49 & 100 \\
15.3 & 710 & 6.39 & 500 & 5.17 & 57.0 & 2.59 & 1.49 \\
18.9 & 720 & 10.6 & 470 & 9.04 & 55.7 & 4.25 & 100 \\
22.5 & 730 & 12.2 & 490 & 10.6 & 58.3 & 5.19 & 100 & 100
\end{tabular}




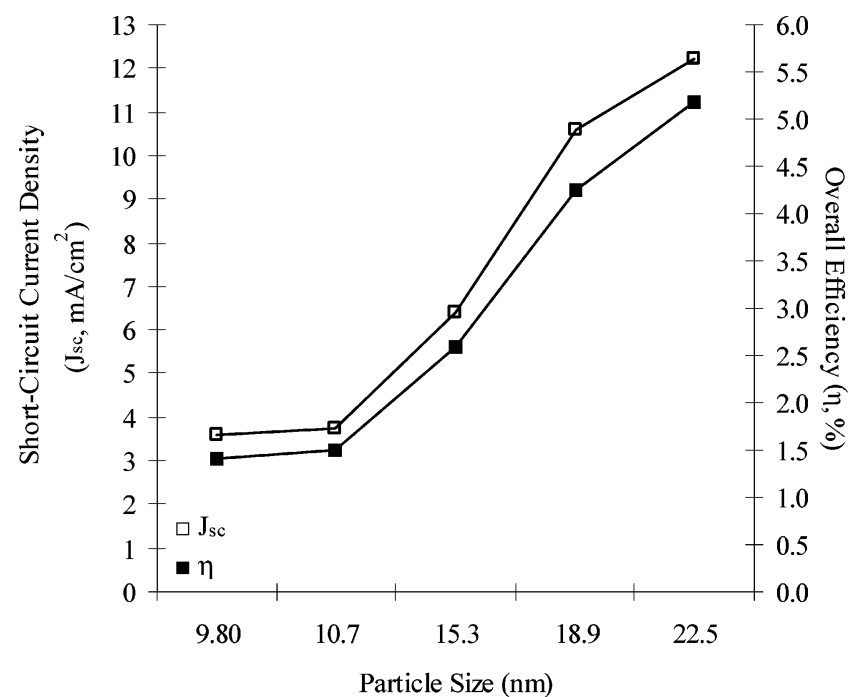

Figure 5. Comparison of the short-circuit current density and the overall light conversion efficiency as a function of particle size. With increasing particle size, the short-circuit current density and overall light conversion efficiency increases.

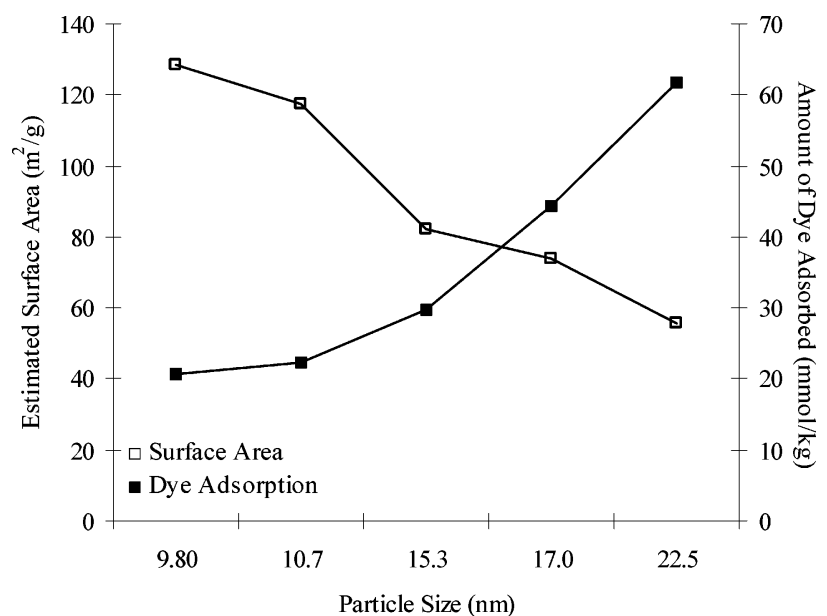

Figure 6. Comparison of the estimated surface area and the amount of dye adsorbed on $\mathrm{TiO}_{2}$ nanoparticle film as a function of particle size. With increasing particle size, the surface area decreases but the amount of dye adsorption increases.

increase in particle size could be due to the better dye adsorption characteristics of the larger particles. More dye adsorption can also be influenced by the presence of larger contact points for easier access of the dye, which would increase the generation of electron-hole pairs. This increase in the generation of electron-hole pairs with increasing particle size is evidenced by the increase in short-circuit current density values, as previously indicated. To compare the dye adsorption characteristics of the $\mathrm{TiO}_{2}$ films with various particle sizes, optical analysis of the resultant $\mathrm{N} 3$ dye after the immersion of each film was compared to that of the initial N3 dye solution to calculate the amount of dye adsorbed onto each film. Figure 6 compares the estimated surface area and the amount of dye adsorbed on the surface of each $\mathrm{TiO}_{2}$ nanoparticle film relative to the particle size. Table 3 summarizes the values of surface area, amount of dye adsorbed, and overall light conversion efficiency of the prepared $\mathrm{TiO}_{2}$ films relative to the particle size obtained by hydrothermal treatment at various temperatures and additional sintering at $500{ }^{\circ} \mathrm{C}$ for $60 \mathrm{~min}$.

It was found that the amount of dye adsorbed on the surface increased with increasing particle size. This is interesting to note since the amount of surface area allowable for dye adsorption

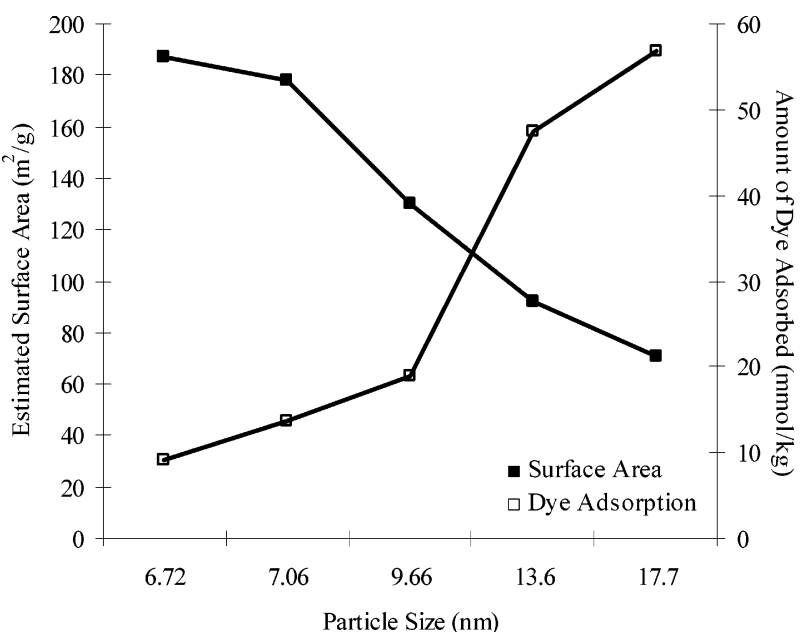

Figure 7. Comparison of the estimated surface area and the amount of dye adsorbed on $\mathrm{TiO}_{2}$ nanoparticle powders obtained by hydrothermal treatment at various temperatures. With increasing particle size, the surface area decreases but the amount of dye adsorption increases.

TABLE 3: Summary of the Amount of Dye Adsorbed and the Overall Light Conversion Efficiency of $\mathrm{TiO}_{2}$ Nanoparticle Films Relative to the $\mathrm{TiO}_{2}$ Particle Size and Surface Area

\begin{tabular}{cccccc}
\hline $\begin{array}{c}\text { temperature } \\
\left({ }^{\circ} \mathrm{C}\right)\end{array}$ & $\begin{array}{c}\text { time } \\
(\text { minutes })\end{array}$ & $\begin{array}{c}\text { particle } \\
\text { size }(\mathrm{nm})\end{array}$ & $\begin{array}{c}\text { surface } \\
\text { area }\left(\mathrm{m}^{2} / \mathrm{g}\right)\end{array}$ & $\begin{array}{c}\text { dye } \\
\text { adsorption } \\
(\mathrm{mmol} / \mathrm{kg})\end{array}$ & $\begin{array}{c}\text { overall } \\
\text { efficiency } \\
(\%)\end{array}$ \\
\hline 100 & 60 & 9.80 & 128.2 & 20.8 & 1.40 \\
150 & 60 & 10.7 & 117.4 & 22.4 & 1.49 \\
200 & 60 & 15.3 & 82.1 & 29.9 & 2.59 \\
250 & 60 & 17.0 & 73.9 & 44.5 & 4.25 \\
300 & 60 & 22.5 & 55.8 & 61.8 & 5.19
\end{tabular}

decreased with increasing particle size. One possible explanation for this trend was brought up by Grant et al., ${ }^{24}$ where it was reported that smaller particles resulted in smaller pore sizes and larger particles resulted in larger pore sizes after sintering at elevated temperatures. The work in Grant et al. concentrated on the use of much larger bulky polymers for pore filling, where the difference in pore size is important for the access of the long-chain conjugated polymer sensitizer. In this case, however, it is possible that the larger particles sintered together resulted in larger pore sizes for easier access of dye, but since the dye is relatively small, the pore size may not have been a major factor in the amount of dye adsorbed.

To show that the pore size may or may not have played a role in the amount of dye adsorbed, the amount of dye adsorbed on $\mathrm{TiO}_{2}$ nanoparticle powder before film formation and sintering at elevated temperature was analyzed and compared. On the basis of this analysis, it was determined that the amount of dye adsorbed was not completely influenced by the pore size. Figure 7 compares the estimated surface area and the amount of dye adsorbed on the surface of the various $\mathrm{TiO}_{2}$ nanoparticle powders relative to the particle size. Table 4 summarizes the values of the estimated surface area and the amount of dye adsorption of the prepared $\mathrm{TiO}_{2}$ powders relative to the particle size obtained by hydrothermal treatment at various temperatures.

By utilizing the $\mathrm{TiO}_{2}$ nanoparticle powders to determine and compare the amount of dye adsorbed, it can be determined whether the surface area influenced the amount of dye adsorbed without the pore size as an influential factor. From the analysis, it was also found that the amount of dye adsorbed on the surface increased with increasing particle size, even with the decrease in the amount of surface area allowable for dye adsorption. It was anticipated that the amount of dye adsorption would 
TABLE 4: Summary of the Particle Size, the Estimated Surface Area, and the Amount of Dye Adsorption of $\mathrm{TiO}_{2}$ Nanoparticle Powders Obtained by Varying the Hydrothermal Treatment Temperature for $60 \mathrm{~min}$

\begin{tabular}{ccccc}
\hline $\begin{array}{c}\text { temperature } \\
\left({ }^{\circ} \mathrm{C}\right)\end{array}$ & $\begin{array}{c}\text { time } \\
(\text { minutes })\end{array}$ & $\begin{array}{c}\text { particle } \\
\text { size }(\mathrm{nm})\end{array}$ & $\begin{array}{c}\text { surface } \\
\text { area }\left(\mathrm{m}^{2} / \mathrm{g}\right)\end{array}$ & $\begin{array}{c}\text { dye adsorption } \\
(\mathrm{mmol} / \mathrm{kg})\end{array}$ \\
\hline 100 & 60 & 6.72 & 186.9 & 9.18 \\
150 & 60 & 7.06 & 177.9 & 13.6 \\
200 & 60 & 9.66 & 130.0 & 18.9 \\
250 & 60 & 13.6 & 92.4 & 47.5 \\
300 & 60 & 17.7 & 71.0 & 56.8
\end{tabular}

increase with decreasing particle size or, in other words, increasing surface area.

However, this was not the case, indicating that the surface area and the pore size were not factors in the amount of dye adsorbed. If the trend for $\mathrm{TiO}_{2}$ powder showed that the amount of dye adsorbed increased with increasing surface area, or decreasing particle size, then it can be determined that the pore size played a role in the amount of dye adsorbed since the trend for $\mathrm{TiO}_{2}$ films and powders differed. It was initially thought that the pore size had more of an influence on the amount of dye adsorbed on the surface than the actual surface area. However, the similarity in the trend for the amount of dye adsorbed for both $\mathrm{TiO}_{2}$ nanoparticle films and powders shows that other factors most likely played a role in influencing the amount of dye adsorption.

One possibility previously mentioned for the decreased dye adsorption with decreased particle size is that films with smaller particles have smaller pores that may restrict the access and adsorption of dye molecules. However, the data showing similar dye adsorption trends for $\mathrm{TiO}_{2}$ nanoparticle powders and films contradict this possibility. The size of the dye molecules is also relatively small, which would lead us to believe that pore size was not a factor in the difference in dye adsorption.

Other possibilities for influencing the dye adsorption on the surface of $\mathrm{TiO}_{2}$ could be (1) the variation in the facets obtained from varying the hydrothermal treatment temperature and (2) the variation in the surface curvature of sintered particles as influenced by the particle size, both of which surface energy may depend upon. The variation in facets with varying hydrothermal treatment temperature may show differences in surface energy ${ }^{25}$ after sintering, where facets obtained at higher temperatures may result in higher surface energy and facets obtained at lower temperatures may result in lower surface energy. In addition, the smaller or larger curvature at the contact points between particles after sintering may lead to lower and higher surface energy, respectively.

On the basis of the results obtained for $\mathrm{TiO}_{2}$ nanoparticles obtained by hydrothermal treatment at $250{ }^{\circ} \mathrm{C}$ for various times, the results indirectly show that the surface energy may be one of the key parameters. Figure 8 compares the estimated surface area and the amount of dye adsorbed on the surface of the various $\mathrm{TiO}_{2}$ nanoparticle powders relative to the particle size. Table 5 summarizes the values of particle size in powder form obtained by hydrothermal treatment at various times and the amount of dye adsorbed relative to the particle size. It was found that the particle size slightly increased with increasing time; however, the amount of dye adsorbed remained fairly constant with a variation within $1-2 \mathrm{mmol} / \mathrm{kg}$. The dye adsorption behavior of the $\mathrm{TiO}_{2}$ nanoparticles was very similar and did not vary dramatically with increasing hydrothermal treatment time. Since the particles were all synthesized at the same temperature, the surface morphology of the particles in all cases is expected to be very similar; thus, the surface energy is expected to be similar as well.

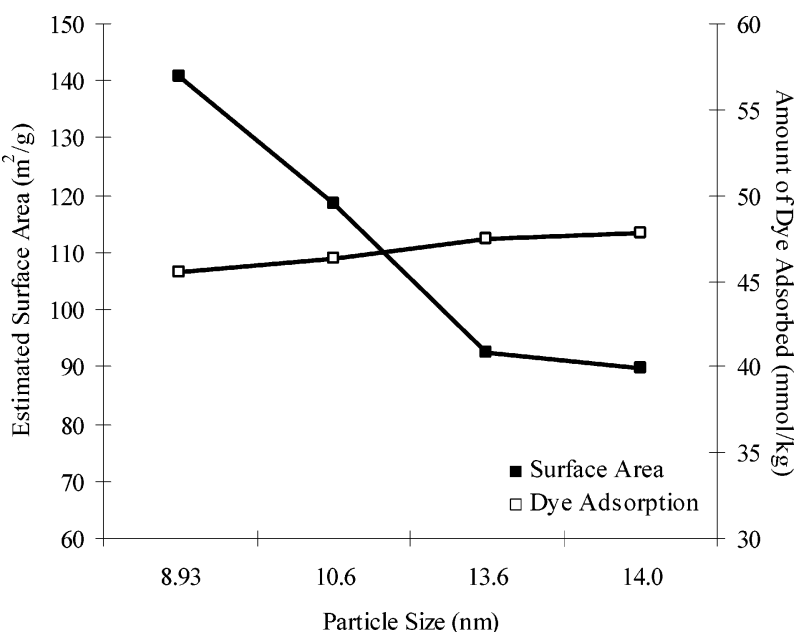

Figure 8. Comparison of the estimated surface area and the amount of dye adsorbed on $\mathrm{TiO}_{2}$ nanoparticle powders obtained by hydrothermal treatment at various times. With increasing particle size, the surface area decreases but the amount of dye adsorption remains fairly constant.

TABLE 5: Summary of the Particle Size, the Estimated Surface Area, and the Amount of Dye Adsorption of $\mathrm{TiO}_{2}$ Nanoparticle Powders Obtained by Varying the Hydrothermal Treatment Time at $250{ }^{\circ} \mathrm{C}$

\begin{tabular}{ccccc}
\hline $\begin{array}{c}\text { temperature } \\
\left({ }^{\circ} \mathrm{C}\right)\end{array}$ & $\begin{array}{c}\text { time } \\
(\text { minutes })\end{array}$ & $\begin{array}{c}\text { particle } \\
\text { size }(\mathrm{nm})\end{array}$ & $\begin{array}{c}\text { surface } \\
\text { area }\left(\mathrm{m}^{2} / \mathrm{g}\right)\end{array}$ & $\begin{array}{c}\text { dye adsorption } \\
(\mathrm{mmol} / \mathrm{kg})\end{array}$ \\
\hline 250 & 20 & 8.93 & 140.6 & 45.5 \\
250 & 40 & 10.6 & 118.5 & 46.3 \\
250 & 60 & 13.6 & 92.4 & 47.5 \\
250 & 120 & 14.0 & 89.7 & 47.8
\end{tabular}

The similarity in the dye adsorption behavior independent of the particle size for $\mathrm{TiO}_{2}$ nanoparticles obtained by hydrothermal treatment at $250{ }^{\circ} \mathrm{C}$ for various times possibly indicates that the dye adsorption behavior may have been influenced by the surface energy related to the variation in facets or surface curvature possibly obtained at varying hydrothermal treatment temperatures. There is some evidence to support the idea that the surface energy may play a key role in the difference in dye adsorption between large and small particles. However, it is inconclusive as to the exact reasoning behind the difference in dye adsorption behavior relative to the particle size. Therefore, further studies into the structure of the facets and the surface curvature of sintered particles in relation to the corresponding surface energy are required to understand the effect of $\mathrm{TiO}_{2}$ particle size on the dye adsorption. This area of study would be worthy of pursuing in future work to identify the exact reasoning for the dye adsorption trend, where films and powders with larger particles adsorb more dye than that with smaller particles.

\section{Conclusions}

It was found that larger particles resulted in higher shortcircuit current density and overall light conversion efficiency. Films consisting of $\mathrm{TiO}_{2}$ nanoparticles with $\sim 10 \mathrm{~nm}$ diameter resulted in a short-circuit current density of $\sim 3.6 \mathrm{~mA} / \mathrm{cm}^{2}$ and an overall light conversion efficiency of $\sim 1.4 \%$. With an increase in the particle size to $\sim 23 \mathrm{~nm}$ diameter, a higher shortcircuit current density of $\sim 12.2 \mathrm{~mA} / \mathrm{cm}^{2}$ and a higher overall light conversion efficiency of $\sim 5.2 \%$ was obtained. This increase in short-circuit current density and overall light conversion efficiency, which correlates with the increase in particle size, may have been due to the better dye adsorption behavior of the larger $\mathrm{TiO}_{2}$ nanoparticles, where larger particles 
allow for more dye adsorption through easier access of dyes, resulting in a greater generation of electrons and holes.

Acknowledgment. T. P. Chou acknowledges the UW-PNNL Joint Institute for Nanoscience (JIN), jointly funded by the University of Washington (UW) and the Pacific Northwest National Laboratory (PNNL, operated by Battelle for the U.S. Department of Energy), and the Intel Ph.D. Foundation for their financial support. We also acknowledge the Air Force Office of Scientific Research (AFOSR-MURI, FA9550-06-1-032) for partial financial support and Professor Samson Jenekhe and Dr. Abhishek Pradeep Kulkarni for the use of their lab and solar cell testing equipment.

\section{References and Notes}

(1) Cahen, D.; Hodes, G. J. Phys. Chem. B 2000, 104, 2053.

(2) Grätzel, M. Prog. Photovoltaics 2000, 8, 171

(3) Hagfeldt, A.; Grätzel, M. Chem. Rev. 1995, 95, 49.

(4) Green, M. A. Prog. Photovoltaics 2001, 9, 123.

(5) Hodes, G.; Howell, I. D. J.; Peter, L. M. J. Electrochem. Soc. 1992, 139,3136

(6) Grätzel, M. Chem. Lett. 2005, 34, 8 .

(7) Grätzel, M. Nature 2001, 414, 338.

(8) Hagfeldt, A.; Grätzel, M. Acc. Chem. Res. 2000, 33, 269.

(9) Barbé, C. J.; Arendse, F.; Comte, P.; Jirousek, M.; Lenzmann, F.; Shklover, V.; Grätzel, M. J. Am. Ceram. Soc. 1997, 80, 3157.
(10) Grätzel, M. J. Photochem. Photobiol., C: Photochem. Rev. 2003, $4,145$.

(11) Hagfeldt, A.; Grätzel, M. Chem. Rev. 1995, 95, 49.

(12) Nazeeruddin, M. K.; Kay, A.; Rodicio, I.; Humphry-Baker, R.; Mueller, E.; Liska, P.; Vlachopoulos, N.; Graetzel, M. J. Am. Chem. Soc 1993, 115, 6382.

(13) Green, M. A.; Emery, K.; King, D. L.; Hishikawa, Y.; Warta, W. Prog. Photovoltaics 2006, 14, 455.

(14) Grätzel, M. J. Photochem. Photobiol., A: Chem. 2004, 164, 3.

(15) Gracia, F.; Holgado, J. P.; González-Elipe, A. R. Langmuir 2004, $20,1688$.

(16) Hagfeldt, A.; Boschloo, G.; Lindstrom, H.; Figgemeier, E.; Holmberg, A.; Aranyos, V.; Magnusson, E.; Malmqvist, L. Coord. Chem. Rev. 2004, 248, 1501 .

(17) Gregg, B. A. Coord. Chem. Rev. 2004, 248, 1215.

(18) Gregg, B. A. J. Phys. Chem. B 2003, 107, 4688.

(19) Kartini, I.; Menzies, D.; Blake, D.; da Costa, J. C. D.; Meredith, P.; Riches, J. D.; Lu, G. Q. J. Mater. Chem. 2004, 14, 2917.

(20) Zhang, D.; Yoshida, T.; Furuta, K.; Minoura, H. J. Photochem. Photobiol., A: Chem. 2004, 163, 159.

(21) Limmer, S. J.; Chou, T. P.; Cao, G. Z. J. Mater. Sci. 2004, 39, 895.

(22) Wu, Z.; Joo, H.; Ahn, I.-S.; Kim, J.-H.; Kim, C.-K.; Lee, K. J. Non-Cryst. Solids 2004, 342, 46.

(23) Cullity, B. D. Elements of X-Ray Diffraction, 2nd ed.; AddisonWesley: Boston, MA, 1956.

(24) Grant, C. D.; Schwartzberg, A. M.; Smestad, G. P.; Kowalik, J.; Tolbert, L. M.; Zhang, J. Z. J. Electroanal. Chem. 2002, 40, 522.

(25) Gong, X.-Q.; Selloni, A.; Batzill, M.; Diebold, U. Nat. Mater. 2006 5,665 . 